\title{
GENETIC DIVERSTY
}

Leaf endophytic fungi of chili (Capsicum annuum) and their role in the protection against

187-191 Aphis gossypii (Homoptera: Aphididae)

HENY HERNAWATI, SURYO WIYONO, SUGENG SANTOSO

Isolation and identification of an agar-liquefying marine bacterium and some properties of its extracellular agarases

FATURRAHMAN, ANJA MERYANDINI, MUHAMMAD ZAIRIN JUNIOR, IMAN RUSMANA

\section{ECOSYSTEM DIVERSTY}

Soil microorganisms numbers in the tailing deposition ModADA areas of Freeport

IRNANDA AIKO FIFI DJUUNA, MARIA MASORA, PRATITA PURADYATMIKA

Inventorying of the tree fern Genus Cibotium of Sumatra: Ecology, population size and

distribution in North Sumatra

TITIEN NGATINEM PRAPTOSUWIRYO, DIDIT OKTA PRIBADI, DWI

MURTI PUSPITANINGTYAS, SRI HARTINI

Species composition and interspecific association of plants in primary succession of Mount Merapi, Indonesia

SUTOMO, DINI FARDILA, LILY SURAYYA EKA PUTRI

Establishing a long-term permanent plot in remnant forest of Cibodas Botanic Garden, West Java

ZAENAL MUTAQIEN, MUSYAROFAH ZUHRI

Analysis of epiphytic orchid diversity and its host tree at three gradient of altitudes in Mount Lawu, Java

NINA DWI YULIA, SUGENG BUDIHARTA, TITUT YULISTYARINI

Valuing quality of vegetation in recharge area of Seruk Spring, Pesanggrahan Valley, Batu

City, East Java

TITUT YULISTYARINI, SITI SOFIAH

Termites community as environmental bioindicators in highlands: a case study in eastern slopes of Mount Slamet, Central Java

TEGUH PRIBADI, RIKA RAFFIUDIN, IDHAM SAKTI HARAHAP

\section{ETHNOBIOLOGY}

Community-based sustainable rattan conservation: a case study in Lore Lindu National Park, Central Sulawesi

HAMZARI

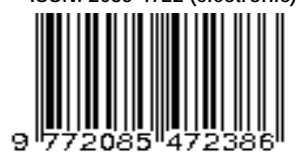


